\title{
Honeybee Production and Honey Quality Assessment in Guji Zone, Ethiopia
}

Birhanu Tesema Areda*

Faculty of Agricultural Sciences, Department of Animal and Range Science, Blue Hora University, Ethiopia

\begin{abstract}
Assessment of Honeybee production practices and quality assessment were undertaken in Guji district of Ethiopia. Honey samples were collected from farmers' hives and local honey market for chemical analysis to determine its quality. Physicochemical analysis of honey was carried out at Haramaya University Animal Nutrition and Food Science technology. All physicochemical parameters analyzed lie within limits of local and international standard. Honey laboratory analysis was subjected to one way ANOVA of SAS. Above all, improving the low level of technological input and honey quality defects, address the skill gap on postharvest handling of hive products, processing and packaging need a practical training to local beekeepers. Moreover, facilitating supply of quality apicultural equipment is crucial and further consistent practical training on bee and bee products management for community is recommended.
\end{abstract}

Keywords: Honey bee; Physio-chemical property; Honey quality

\section{Introduction}

Honey is a natural substance produced by bees and nutritious food of economic importance worldwide. It is a sweet viscous liquid that is composed of sugars, amino acids, proline, minerals, aromatic substances, pigment waxes and grains $[1,2]$ and contains large amount of glucose but low in sucrose $(<8 \%)$ [3]. Honey is easily digestible and a more palatable which supplies substantial energy with 75 to $85 \%$ fructose and glucose. The physicochemical composition, flavour and colour of honey vary due to climate, soil, flora, bee species and production methods. The precise composition variation depending on the plant species on which bee forages are the main constituents $[4,5]$. Storage conditions may also influence final composition, with the proportion of disaccharides increasing overtime [6]. Careless handling of honey can reduce quality like, high temperature, length of storage and moisture content which lead to fermentation, high levels of Hydroxy-methylfurfural (HMF), loss of enzymatic microbial growth [7]. Therefore, this study was designed to collect information on production system, productivity, bee flora and post managements of honey and determine its quality.

\section{Materials and Methods}

\section{Sampling techniques and sample size}

The study was conducted in beekeeping potential of Guji Zone. A total of 16 honey samples were purposively selected from four of beekeeper peasants of the zone and a sample of honey from market. A half $(1 / 2) \mathrm{kg}$ of honey samples were collected from two types of hives for laboratory analysis.

\section{Collected data}

The study was requiring wide range of information with reference to beekeeping. The chemical compositions of honey samples was determined accordingly $[8,9]$ in the laboratory.

Moisture content: The moisture content of honey was determined by using the refractive index of the honey.

The table is derived from a formula developed by Wedmore E [10] and calculated by:

$$
\mathrm{W}=\frac{1.73190-\log (\text { R.I }-1)}{0.002243}
$$

\section{Where}

$\mathrm{W}=$ Water content in $\mathrm{g} / 100 \mathrm{~g}$ honey and R.I. is the refractive index

Mineral (ash) content: Ash content was determined after the sample burnt in an electric muffle furnace. Percent ash g/100 g honey was calculated by using:

$$
\text { Ash } \%=\frac{M_{1}-M_{2}}{M_{0}} \times 100
$$

Where $\mathrm{M}_{0}$ =weight of honey, $\mathrm{M}_{1}=$ weight of dish + ash and, $\mathrm{M}_{2}=$ weight of dish.

pH and free acidity: The $\mathrm{pH}$ of sample was measured with $\mathrm{pH}$ meter and the solution was further titrated with $0.1 \mathrm{M}$ sodium hydroxide $(\mathrm{NaOH})$ solution to $\mathrm{pH} 8.30$.

\section{Acidity $=10 \mathrm{~V}$}

Where

\section{$\mathrm{V}=$ the volume of $0.1 \mathrm{~N} \mathrm{NaOH}$ in $10 \mathrm{~g}$ honey}

Reducing sugar: This method is a modification of the Lane and [11] procedure, involving the reduction of Soxhlet's modification of Fehling's solution by titration at boiling point against a solution of reducing sugars in honey using methylene blue as an internal indicator and expression of result:

$$
\mathrm{C}=\frac{2 \times 1000}{\mathrm{~W}_{2} \mathrm{Y}_{2}}
$$

Where

*Corresonding author: Birhanu Tesema Areda, Faculty of Agricultural Sciences, Department of Animal and Range Science, Blue Hora University, Ethiopia, Tel: +251911857349; E-mail: berhan2m@gmail.com

Received September 24, 2015; Accepted October 12, 2015; Published October 19, 2015

Citation: Areda BT (2015) Honeybee Production and Honey Quality Assessment in Guji Zone, Ethiopia. J Food Process Technol 6: 512. doi:10.4172/2157 7110.1000512

Copyright: ( 2015 Areda BT. This is an open-access article distributed under the terms of the Creative Commons Attribution License, which permits unrestricted use, distribution, and reproduction in any medium, provided the original author and source are credited. 
$\mathrm{C}=\mathrm{g}$ invert sugar per $100 \mathrm{~g}$ honey

$\mathrm{W}_{2}=$ weight $(\mathrm{g})$ of honey sample

$\mathrm{Y}_{2}=$ volumes $(\mathrm{ml})$ of diluted honey solution

Apparent sucrose: The procedure of determining reducing sugar was

ASC $=($ invert sugar content after inversion - invert sugar content before inversion) $\times 0.95$

Where

\section{ASC $=$ Apparent sucrose content}

The result will be expressed as g apparent sucrose per $100 \mathrm{~g}$ honey

Data Management and Statistical Analysis: Honey quality parameters were analyzed by using one way ANOVA and \pm SD.

\section{Results and Discussion}

\section{Feeding honey bees and flora condition}

Honey bee colonies naturally withstand themselves and produce honey by foraging natural and cultivated crops and store honey for their own feeding during dearth period. But, beekeepers are harvesting honey which honey bees stored for them. The management for honey bees is very minimal in the study area. During the survey period it was observed that some farmers who have modern beehives (33.33\%) were manage and $66.67 \%$ did not manage it properly. With regard to type of feed they provide, respondent feeding their bees $(36.67 \%)$ use honey and pea flour (3.33\%), pea flour and sugar syrup (6.67\%), sugar syrup (10.0\%) and pea flour (16.67.8\%). 63.33\% beekeepers were not give anything to honey bees as food.

\section{Hive products harvesting and post handling}

The frequency and amount of honey harvested varied depending on flowering condition of major bee forage, colony management practices and number of beehive [12]. In the study area, honey harvesting periods were from March to April and July to August where harvesting periods correlate with availability of moisture and peak flowering period. During honey harvested, beekeepers cut and pull the fixed combs one by one and then pollen, brood and honey combs were removed, and kept in a container and covered with a lid which affects quality of honey in relation to length of storage. According to Gichora [13], plastic container is the ideal one for the quality of honey. Accordingly plastic bucket and plastic sack were highly used and in some case they use nickels to store honey for both short and long period and which result rusting; deteriorates the honey and technically not appropriate for storage facilities.

\section{Honey bee flora}

Beekeeping is more dependable on ecological suitability of an area than any other livestock production [14] and, honey bee population and their productivities in general are mainly influenced by the nature of honey bee flora. Vegetation characteristics of the study areas are considered to be an important indicator for the potentialities of the area for beekeeping. Survey conducted showed that, the potential of cultivated and natural honey flora makes it very favorable for beekeeping. The respondents pointed that, even though there are different types of bee plants and flora seasons, there is a shortage of bee feed during the dry seasons where ground and surface water resources are limited. They also indicated that bee forages become declined as compared with the past period due to forest degradation, use of herbicides and expansion of cultivated lands in the area.

\section{Honey quality laboratory result}

Physicochemical properties of honey produced in the study area were analyzed compared to Quality and Standards Authority of Ethiopia (QSAE), Codex Alimentarius Commission (CAC) and European Union (EU) were described below.

Moisture: The mean moisture contents of honey samples collected from different locations and hive types are reported below which is depends on the environmental conditions such as temperature, relative humidity of the area and the manipulation of honey during harvesting period by beekeepers, and seasonal variation $[15,16]$.

Ash: The minimum, maximum and mean ash contents of the honey samples analyzed in the present study was lower than the maximum limits $(0.6 \%)$ set for ash content of the honey by EU, CA and QSAE and the average was within the national and international limits for ash content of honey.

Free acidity: The overall mean free acidity of honey samples analyzed was $24.08 \%$ which is within the acceptable limits $(\leq 40$ $\mathrm{meq} / \mathrm{kg}$ ) set by QSAE and CAC, whereas the limit for honey acidity according to EU (2002) honey standard is $\leq 50 \mathrm{meq} / \mathrm{kg}$. None of the samples exceeded the limit set, which may be taken as indicative of freshness of all the honey samples of the study area. Variation in free acidity among different honeys can be attributed to floral origin or to variation in the harvest season [17].

$\mathbf{p H}$ : There was no significant difference $(\mathrm{p}>0.05)$ in $\mathrm{pH}$ between honey samples obtained from traditional (3.45) and modern hives (4.03) (Table 1), similarly, no significant difference in acidity observed was also other factor. Honey $\mathrm{pH}$ has great importance during storage of honey, as they influence the texture, stability and shelf life of honey [18]. $\mathrm{pH}$ of honey samples in the current study ranged from 4.13 to 5.02 , with an average value of 4.45 (Table 3 ).

Reducing sugars: The overall mean reducing sugar content of the analyzed honey samples was $76 \%$ which within quality requirement limits ( $\geq 65 \%$ ) (QSEA; CAC; EU). There were no significant differences $(\mathrm{P}>0.05)$ in reducing sugars content between honey samples obtained from the two hive types and locations (Tables 1 and 2). Similarly, the average reducing sugars content of honey obtained from market location $(80.2 \%)$ was significantly higher $(\mathrm{p}<0.05)$ than the average moisture content of honey obtained from the two agro ecologies (collected directly from beekeepers).

Apparent sucrose: Apparent sucrose are set to be $5 \mathrm{~g} / 100 \mathrm{~g}$ for the majority of honeys, which have higher limits $(10 \mathrm{~g} / 100 \mathrm{~g})$, as well as

\begin{tabular}{|c|c|c|c|}
\hline \multirow{2}{*}{ Variables } & \multicolumn{3}{|c|}{ Location } \\
\cline { 2 - 4 } & $\begin{array}{c}\text { Shakiso }(\mathbf{n = 8}) \\
\text { Mean } \pm \text { SD }\end{array}$ & $\begin{array}{c}\text { Adola (n=8) } \\
\text { Mean } \pm \text { SD }\end{array}$ & $\begin{array}{c}\text { Market (n=2) } \\
\text { Mean } \pm \text { SD }\end{array}$ \\
\hline Moisture content $(\mathrm{g} / 100 \mathrm{~g})$ & $15.12 \pm 0.74$ & $14.28 \pm 0.89$ & $13.20 \pm 0.76$ \\
\hline $\begin{array}{c}\text { Reducing sugars content } \\
\text { (g/100 g) }\end{array}$ & $60.8 \pm 1.28^{*}$ & $60.45 \pm 1.12$ & $67.72 \pm 1.28$ \\
\hline Apparent sucrose (g/100 g) & $3.0 \pm 1.14$ & $3.62 \pm 1.23$ & $2.94 \pm 1.32$ \\
\hline Ash content $(\mathrm{g} / 100 \mathrm{~g})$ & $0.34 \pm 0.48$ & $0.36 \pm 0.58$ & $0.20 \pm 0.34$ \\
\hline Free acid (meqkg $\left.{ }^{-1}\right)$ & $19.26 \pm 0.00$ & $16.38 \pm 3.28$ & $14.10 \pm 2.00^{*}$ \\
\hline $\mathrm{pH}$ & $3.22 \pm 0.17$ & $3.24 \pm 0.21$ & $3.29 \pm 0.07$ \\
\hline
\end{tabular}

$\mathrm{SD}=$ standard deviation; * significantly different $(\mathrm{p}<0.05) ;{ }^{*}$ significantly different $(p<0.01)$. meq = milli equivalent; $n=$ number of samples; means followed by different superscript letters in a row are significantly different.

Table 1: Comparison of physicochemical properties of honey samples collected from different locations. 
Citation: Areda BT (2015) Honeybee Production and Honey Quality Assessment in Guji Zone, Ethiopia. J Food Process Technol 6: 512. doi:10.4172/2157-7110.1000512

\begin{tabular}{|c|c|c|}
\hline \multirow{2}{*}{ Variables } & \multicolumn{2}{|c|}{ Hive type } \\
\cline { 2 - 3 } & $\begin{array}{c}\text { Traditiona }(\mathbf{n = 8}) \\
\text { Mean } \mathbf{~} \text { SD }\end{array}$ & $\begin{array}{c}\text { Movable frame }(\mathbf{n}=\mathbf{8}) \\
\text { Mean } \pm \text { SD }\end{array}$ \\
\hline Moisture content $(\mathrm{g} / 100 \mathrm{~g})$ & $13.67 \pm 1.20$ & $13.62 \pm 1.40$ \\
\hline Reducing sugars content $(\mathrm{g} / 100 \mathrm{~g})$ & $60.84 \pm 0.62$ & $60.07 \pm 0.78$ \\
\hline Apparent sucrose $(\mathrm{g} / 100 \mathrm{~g})$ & $3.22 \pm 0.86$ & $3.33 \pm 1.39$ \\
\hline Ash content $(\mathrm{g} / 100 \mathrm{~g})$ & $0.22 \pm 0.10$ & $0.52 \pm 0.75$ \\
\hline Free acid $\left(\mathrm{meqkg}^{-1}\right)$ & $14.46 \pm 3.40^{\mathrm{b} *}$ & $16.52 \pm 3.76^{\text {** }}$ \\
\hline $\mathrm{pH}$ & $3.40 \pm 0.25$ & $3.69 \pm 0.19$ \\
\hline
\end{tabular}

$\mathrm{SD}=$ Standard deviation; meq=milli equivalent; $n=$ Number of samples; Means followed by different superscript letters in a row are; *significantly different $(p<0.05)$

Table 2: Comparison of physicochemical properties of honey samples collected from different hive types.

\begin{tabular}{|c|c|c|c|c|}
\hline \multirow[t]{2}{*}{ No. } & \multirow[t]{2}{*}{ Variable } & \multirow[t]{2}{*}{ Unit } & \multicolumn{2}{|c|}{ Current study } \\
\hline & & & Range & Mean \pm SD \\
\hline 1 & Moisture & $\mathrm{g} / 100 \mathrm{~g}$ & $12.72-19.04$ & $14.35 \pm 1.50$ \\
\hline 2 & Reducing sugars & $\mathrm{g} / 100 \mathrm{~g}$ & $59.52-61.60$ & $68.4 \pm 1.19$ \\
\hline 3 & Apparent sucrose & $\mathrm{g} / 100 \mathrm{~g}$ & $1.61-4.81$ & $2.22 \pm 0.9$ \\
\hline 4 & Ash & $\mathrm{g} / 100 \mathrm{~g}$ & $0.26-1.42$ & $0.34 \pm 0.38$ \\
\hline 5 & Free acid & meqkg $^{-1}$ & 12.33- 27.74 & $13.2 \pm 5.42$ \\
\hline 6 & $\mathrm{pH}$ & & $3.82-4.02$ & 4. $50 \pm 0.33$ \\
\hline
\end{tabular}

$\mathrm{CAC}=$ Codex Alimentarius Commission; $\mathrm{EU}=$ European Union; $\mathrm{meq}=$ milliequivalent; $\mathrm{n}$ : Number of samples; $\mathrm{SD}=$ standard deviation; $\mathrm{QSEA}=$ Quality and Standards Authority of Ethiopia.

Table 3: Physicochemical properties of honey produced in the study area in relation to national and international standards.

lavender honeys (15 g/100 g) (EC Directive 2001/110). Higher sucrose contents could be the result of an early harvest of honey, i.e., the sucrose has not been converted to fructose and glucose $[19,20]$. The amount of sucrose in honey differs according to the degree of maturity and nectar compound of the honey (Tables 1-3).

\section{Summary and Recommendation}

Laboratory evaluation showed that the mean moisture, reducing sugars, sucrose, acidity, ash and $\mathrm{pH}$ contents of the honey samples collected from the study area revealed that, all the physicochemical parameters lie with-in limits of local and international standards set by Quality and Standards Authority of Ethiopia, Codex Alimentarius Commission and EU Council. There were significant differences for acidity and water insoluble solids $(\mathrm{p}<0.01)$ between hive types. But, there were no significant differences $(p<0.05)$ between hive types and among locations for moisture, reducing sugar, sucrose, ash, and $\mathrm{pH}$ contents of honey samples tested. Therefore, to improve the low level of technological input utilization, it needs to be facilitate the supply improved bee-hives, honey processing materials and other beekeeping equipment, address the skill gap on bee colony management and postharvest handling of hive products, further consistent practical training on bee and bee products management for community is recommended.

\section{References}

1. Bogdanov SV, Kilchenmann V, Fluri P (1998) American Bee Journal 139: 61-63.

2. Qiu PY, Ding HB, Tang YK, Xu RJ (1999) Determination of Chemical Composition of Commercial Honey by Near-Infrared Spectroscopy. Journal of Agriculture and Food chemistry 47: 2760- 2765.

3. USDA National honey report (2008).

4. Terrab AA, Gonzalez AG, Diez MJ, Francisco JH (2003) Characterisation of Moroccan unifloral honeys using multivariate analysis. Europe Food Research and Technology 218: 88-95.
5. Gulfra MF, Iftikhar MF, Raja S, Asif S, Mehmood S, et al. (2010) Quality Assessment And Antimicrobial Activity Of Various Honey Types Of Pakistan. African Journal of Biotechnology 9: 43-49.

6. White JW, Subers MH (1964) Studies on Honey inhibine: effects of heat Journal of Applied Research 3: 45-50.

7. Moguel O, Carlos EG, Escobedo RM (2005) Physicochemicalquality of honey from honeybees. Apis mellifera produced in the State of Yucatanduring stages of the production process and blossoms 43: 323-334.

8. Bogdanov S (2002) Harmonized Methods of the International Honey Commission. Results for Amhara Region, Statistical Reports onLivestock and Farm Implants, Ababa, Ethiopia.

9. Bultosa G (2005) Food chemistry laboratory manual. Department of food science and post harvest technology, Haramaya University, Ethiopia.

10. Wedmore $E$ (1955) The accurate determination of the water content of honeys Taylor and Francis 24: 197-206.

11. Lane JH, Eynon $L$ (1923) Determination of reducing sugar by means of Fehling's solution with methylene blue as internal indicator. Journal of Soc. Chem. India

12. Kajobe R, Godfrey AJ, Kugonza DR, Alioni V, Otim SA, et al. (2009) National beekeeping calendar, honeybee pest and disease control methods for improved production of honey and other hive products, Uganda.

13. Gichora M (2003) Towards Realization of Kenya's Full Beekeeping Potential. A Case Study of Baringo District. Cuvillier Verlag Gottingen, Germany.

14. Adgaba N (2002) Geographical races of the Honeybees of the Northern Regions of Ethiopia. The Tropical Agriculturalist. The Technical Center forAgriculture and Rural Cooperation (CTA), International Bee ResearchAssociation (IBRA) and Macmillan, Malaysia.

15. Acquarone C, Buera P, Elizalde B (2007) Pattern of $\mathrm{pH}$ and electrical conductivity upon honey dilution as a complementary tool for discriminating geographical origin of honeys. Food Chemistry 101: 695-703.

16. Cantarelli MA, Pellerano RG, Marchevsky EJ, Camina JM (2008) Quality of honey from Argentina: Study of chemical composition and trace elements. The Journal of the Argentine Chemical Society 96: 33-41.

17. Pe'rez-Arquillue C, Conchello P, Arin A, Juan T, Herrera A (1995) Physicochemical attributes and pollen spectrum of some unifloral Spanish honeys. Food Chemistry 54: 167-172.

18. Terrab A, Recamales AF, Hernanz D, Heredia FJ (2004) Characterisation of Spanish thyme honeys by their physicochemical characteristics and mineral contents. Food Chemistry 88: 537-542.

19. Azeredo LC, Azeredo MAA, Souza SR, Dutra VML (2003) Protein contents and physicochemical properties in honey samples of Apis mellifera of different floral origins. Food Chemistry 80: 249-254.

20. Codex Alimentarius Commission (2001) Revised Codex Standard for Honey Joint FAO/WHO Food StandardsProgramme. FAO Headquarters Rome, Italy. 